\title{
KIRJANDUSMUUSEUMI JA HUMANITAARTEADUSTE ÜMBER TOIMUNUD AVALIK DISKUSSIOON AASTATEL 1967-1968
}

\author{
AVE GOR ̌̌S $\check{C}$
}

$\mathrm{T}$ ähtpäevad meelitavad tagasivaateid tegema. ${ }^{1}$ 24. septembril 1927. aastal asutatud Eesti Kirjandusmuuseumi Eesti Rahvaluule Arhiiv tähistab 2017. aasta septembris oma 90. sünnipäeva. 2018. aastal möödub aga 130 aastat Jakob Hurda ajaloolisest rahvaluulekogumise üleskutsest. Hurda kogu oli aluseks nii Eesti Rahva Muuseumi (ERM) asutamisele 1909. aastal kui ka Eesti Rahvaluule Arhiivi (ERA) ellukutsumisele keskse folklooriarhiivi ja ERM-i autonoomse osakonnana. Need asutused olid omavahel seotud kuni mitmekordsete reorganiseerimisteni. 1940. aastal moodustati seni ERM-i alluvuses tegutsenud Arhiivraamatukogust, Eesti Bibliograafia Asutisest, Eesti Rahvaluule Arhiivist ja Eesti Kultuuriloolisest Arhiivist (EKLA) Eesti NSV Riiklik Kirjandusmuuseum (edaspidi kirjandusmuuseum), mis hakkas hiljem alluma Eesti NSV Teaduste Akadeemiale (TA). Aastatel 1942-1944 likvideerisid Saksa võimud kirjandusmuuseumi iseseisva asutusena ning kogud liideti Tartu ülikooliga: ERA ja bibliograafia osakond filosoofia osakonnaga, EKLA ja arhiivraamatukogu ülikooli raamatukoguga. Uue Nõukogude okupatsiooniga taastati 1942. aasta olukord ning rahvaluule osakonnale (arhiivile) jäi peamiselt korraldav, teenindav ja publitseeriv funktsioon, millega püüti eelnevat traditsiooni jätkates siduda ka uurimistööd.

1946. aastal moodustati Tartus samuti Eesti NSV Teaduste Akadeemia alluvuses Keele ja Kirjanduse Instituut (KKI) ning selle sees eraldi rahvaluule sektor, mis tegeles peamiselt teadustööga. 1947. aastal viidi KKI Tallinnasse, mistõttu raskenes nii sealsete teadurite ligipääs arhiivimaterjalidele kui ka folkloristide omavaheline koostöö. Kirjandusmuuseumil ei olnud Teaduste Akadeemia süsteemis instituudi staatust, mis võimaldanuks kõrgemat palgataset ja loomuldasa uurimistöö tegemise õigust. Selle tõttu liiguti ka muuseumi rahvaluule osakonnast mitmel juhul KKI rahvaluule sektorisse. Folkloristlik arhiivi- ja teadustöö nende muutuste tõttu muidugi ei lõppenud.

1960. aastate teisel poolel oli ühiskonnas nn sulaaeg, kuid võimud püüdsid taaskehtestada vahepeal mahenenud kontrolli. Oma mõju NSVL-i sisepoliitikale avaldasid sisepinged sotsialismimaades (Ungaris, Tšehhoslovakkias). Kiiresti arenes NSVL-is suhtlus välismaailmaga ning Eestisse tõi selles osas muutusi Soome presidendi Urho Kaleva Kekkose visiit 1965. aastal. Kirjandus ja ajakirjandus olid allutatud ideoloogilisele kontrollile (Eestis oli selle eest vastutav Eesti NSV Ministrite Nõukogu juures asuv Kirjandus- ja Kirjastusasjade Peavalitsus ehk Glavlit). Tegelikkuses ei õnnestunud kultuurielu hoida rangelt kommunistliku ideoloogia raamides. Teatris, kunstis

${ }^{1}$ Käesolev artikkel on välja kasvanud Ingrid Rüütli 80. sünnipäevale pühendatud etnomusikoloogia seminaril 6. XI 2015 Eesti Kirjandusmuuseumis peetud kõnest, mille tekst ilmus samal aastal ajakirjas Mäetagused (Goršič 2015). 
ja kirjanduses kasutati tõketest hoolimata ära loomingulise vabaduse võimalusi, toimus rahvuskultuuri taasärkamine. Teadusliku uurimistöö võimalused avardusid ennekõike reaalteadustes, aga ka humanitaarteadustes, nagu ajalugu, etnograafia (etnoloogia), kunsti- ja teatriajalugu, populaarseks sai koduuurimine. Laienesid võimalused kasutada arhiivimaterjale. Tartu Riiklikus Ülikoolis ja mujalgi tehti algust sotsioloogilise uurimistööga, mida võimud püüdsid samuti kontrolli all hoida, tekkis filosoofiaga tegelemise buum. (Kuuli 2002: 102-152)

Selles kontekstis arenes kahe ajalehe - Sirbi ja Vasara ning Edasi - veergudel 1967. ja 1968. aastal tõsine debatt humanitaarteaduste hetkeseisu ja arengusuundade üle. Sirbis ja Vasaras langes rõhk bibliograafia ja kultuuriloolise materjali alastele küsimustele ning teaduses kasutatava tehnika ja humanitaarteaduste üldistele probleemidele. Edasis väideldi kitsamalt folkloristliku teadus- ja arhiivitöö ning Eesti NSV Teaduste Akadeemia Fr. R. Kreutzwaldi nimelise Riikliku Kirjandusmuuseumi ${ }^{2}$ teemadel: arutleti rahvaluule osakonna (varasema ja praeguse ERA) ning laiemalt muuseumi kõikide osakondade funktsioonide ja tulevikulahenduste üle. Edasis avaldati ühtlasi artiklitest tõukunud laiema vestlusringi kokkuvõte (Edasi 1968). Tegu oli ajaga, kus humanitaaraladel kasvas nõudlus efektiivse infotöötluse ja tehnika järele. Selles raamistikus avanevad ühtlasi rahvaluule osakonna ja kirjandusmuuseumi toonane seis ja tulevikuplaanid.

Ajakirjanduses oli humanitaarteaduste olukorra, vajaduste ja arengute üle arutelusid peetud ja soovitusi jagatud varemgi, millele osutati käesoleva debatisarja esimeses artiklis (Kahk 1967: 3): hiljuti oli toimunud mõttevahetus eestikeelsetes ajalehtedes avaldatud materjali bibliografeerimise mahajäämuse üle. ${ }^{3}$ Eestis ilmunud ajakirjanduse sisu retrospektiivne analüütiline bibliografeerimine oli kirjandusmuuseumi bibliograafia osakonna põhitöö, millega tegeleti vahelduva eduga ning muutuvate ja lisanduvate töösuundade kiuste. Põhimureks oli töö suur maht ja üliväike töötajaskond, samal ajal kasvas nõudlus kiirelt kättesaadavate andmete järele nii humanitaarteadlaste kui ka koduloouurijate seas. Mõnevõrra aitas olukorda leevendada 1968. aastal Fr. R. Kreutzwaldi nimelise Eesti NSV Riikliku Rahvusraamatukogu juurde loodud rahvusbibliograafia osakond, mis toetas kirjandusmuuseumi bibliograafia osakonna tööd (Adamson 1990: 95-96).

Sama kehtis nii rahvaluule- kui ka kultuurilooliste kogude puhul: suure hulga materjali korrastamisega ei tuldud kirjandusmuuseumis toime nii kiiresti, kui kasutajad või muuseumi töötajad ise oleksid tahtnud. Rahvaluule osakonna jaoks tähendas arhiivitöö toona käsitsi kartoteegikaartide ja registrite kirjutamist: nii kirjutati üht ja sama kaarti mitmeid kordi, et süstematiseerida koopiaid erinevatesse üld- ja temaatilistesse kartoteekidesse, samuti kopeeriti kirjutusmasinal mitmes eksemplaris samu rahvaluuletekste. Kirjutusmasinal ja käsitsi kopeerimine oli tohutult tööjõu- ja ajakulukas. Seega oli tekkinud vajadus tehniliste uuenduste järele: paljundusmasinaid oli vaja nii koopiate kiiremaks tegemiseks uurijatele kui ka kartoteekide loomiseks ja varukoopiateks, mikrofilmimine võimaldas vältida väärtuslike käsikirjade korduvat kasutamist ja kulutamist. Samal põhimõttel ei anta tänapäeval uurijate kätte neid originaalmaterjale, mis on juba digiteeritud.

${ }^{2}$ Sellist nimetust kandis muuseum aastatel 1953-1990.

${ }^{3}$ Vt Veersalu 1966; Annus 1966; Margus 1966; Kään 1966b. Ülevaate bibliografeerimise mureküsimustest annab veel Keel ja Kirjandus 1967. 
Tollast arhiivitööd ja kogumist käsitlenud Janika Oras on osutanud, et korraldustööde tagaplaanile jäämise põhjuseks oli hädavajalik rahvaluule kogumine, mille tingis kaastööliste kõrge iga ja hääbuvad folkloorižanrid, samuti hõivatus läänemeresoome vanasõnade väljaande juures. ${ }^{4} \mathrm{Nii}$ arhiivikui ka teadustöö tegemisel vastandusid kaks vaadet: rahvaluulearhiivi rajaja Oskar Looritsa ideedest lähtuv käsitlus (teadus, kogumine, korraldamine on omavahel seotud), mida jätkuvalt järgisid arhiivitöötajad, ja nõukogudeaegne teaduspoliitika (teadustööd teevad ainult Teaduste Akadeemia instituudid) (Oras 2008: 68-70), millest lähtuti väljaspool rahvaluule osakonda.

\section{Infoteaduse kasutusvõimalused humanitaarteadustes}

14. augustil 1967. aastal võttis Nõukogude Liidu Kommunistliku Partei Keskkomitee ühiskonnateaduste eesmärkide kohta vastu otsuse „Abinõudest ühiskonnateaduste edasiarendamiseks ja nende osa suurendamiseks kommunistlikus ülesehitustöös” (avaldati 23. augustil, vt Rahva Hääl 1967). Dokumendis mainitakse ühe eesmärgina arhiivide ja instituutide tehnilise võimekuse tõstmist ja vajadust organiseerida ühiskonnateaduste alal teadusliku informatsiooni instituut. Tegu oli programmilise tekstiga, kus teadust, sh humanitaarteadusi, nähti kommunismi ülesehitamise vahendina. ${ }^{5}$ Informatsioonikeskuse loomise vajaduse mainimine otsuses andis n-ö ametliku põhjenduse selle kavatsuse üle avalikult arutleda (vt Palli 1970: 321).

1967. aasta septembris avaldas ajaloolane Juhan Kahk ${ }^{6}$ (1928-1998) Sirbis ja Vasaras artikli, mille peamisteks arutelupunktideks olid ühiskonnateaduste hetkeolukord ja areng: mikrofilmiaparaatide, ${ }^{7}$ arvutite ja matemaatiliste mudelite kasutusvõimalused suurte materjalihulkade kiirelt kättesaadavaks tegemiseks ja analüüsiks, samuti sotsioloogia võimalused ja valukohad. Illustratiivse näitena allikatest, mille puhul tehniliste võimaluste rakendamisega annaks palju ära teha, tõi Kahk kirjandusmuuseumi juba toona üpris suured kogud. Ta osutas, et kultuuripärandi uurija peab teadvustama ülesandeid, mis on hetkeprobleemide lahendamiseks vajalikud, suundudes samas tuleviku poole. (Kahk 1967)

Seejärel Sirbis ja Vasaras ilmunud arvamustes tõdeti valdavalt, et humanitaaria ja infotehnoloogia sidumine on hädavajalik valdkonna arenguks ning kohe tuleb alustada vastavate eeltöödega, valmistamaks ette täielikku materjali arvutitega töötlemist. Vaieldi aga sellegi üle, kas publikatsioonide arv võiks olla teadusliku potentsiaali mõõdupuu.

${ }^{4}$ Väljaande koostamisest täpsemalt vt Krikmann 2000.

${ }^{5}$ Nõukogude aja alguses anti rahvaluuleuurimises ideoloogilisi suuniseid nii kogutava materjali sisu kui ka uurimiskõlblike teemade osas (vt Ahven 2007: 476-477, 515-518; Oras 2008: 60-65).

${ }^{6}$ Juhan Kahk võttis oma töödes kasutusele matemaatilis-statistilisi meetodeid ning oli ajaloolise sotsioloogia eestvedajaid. Kompartei liikmena kasutas ta oskuslikult häid sidemeid nõukogude võimuga. Aastatel 1968-1974 töötas Eesti NSV TA Ajaloo Instituudi direktorina.

${ }^{7}$ Kahk suhtus soosivalt Eastman Kodaki arendatud mikrofilmide kodeerimissüsteemi Miracode, mis võimaldas masinal leida materjalile omistatud ühe või mitme kolmekohalise koodi järgi filmilt vajalik lehekülg. - Toim. 
Et Kahk tõi näiteks kirjandusmuuseumi kogud, nägi toonane muuseumi teaduslik sekretär Ingrid Rüütel ${ }^{8}$ (snd 1935) vajadust esitada asutuse seisukohad. Vastuses rõhutas Rüütel, et hetkel humanitaarteadlasi erutav probleemistik - kaasaegse tehnika ja matemaatiliste meetodite kasutuselevõtt osutuvad kindlasti murranguliseks humanitaarteaduste arengus (edaspidi on niimoodi kujunenudki). Rüütel oli arvamusel, et Kahki mainitud moodne tehnika ei suuda lahendada muuseumi suurte kogude (sel hetkel miljon lehekülge rahvaluulet ja kolm miljonit lehekülge kirjandus- ja kultuuriloolisi käsikirju, üle 300000 köite (aja)kirjandust) kõiki vajadusi. Rüütel rõhutas tarvidust tunda masinate iseärasusi enne vastavate tööde planeerimist, samuti materjalide ettevalmistamist ja kirjeldamist, koodide (märksõnastike) loomist, et nende masinaga töötlemisest üleüldse kasu oleks. Tehnikast aitaks suuremat kasu lõigata kõrgel tasemel ettevalmistatud suurem töötajaskond. Toona oletas Rüütel, et masin esialgu veel ei asenda tervikuna kartoteeksüsteeme, kuid ka käsitsi tehtavat korrastustööd võiks planeerida tehnilist arengut silmas pidades. (Rüütel 1967b)

Kirjastustöötaja Endel Pillau (1931-1998) kirjutas vanema perioodika bibliografeerimise probleemidest, leides, et töö aegluse peamiseks põhjuseks on seda tegevate inimeste vähesus ja materjali tohutu hulk. Pillau osutas, et ulatuslik bibliografeerimine nõuab vanema perioodika terviklike komplektide koondamist, mida läheb vaja, kui koostatud bibliograafia kasutamisel hakatakse tellima ka vähekasutatud materjale. Nii bibliografeerimiseks kui ka hävimisohus perioodika säilitamiseks peaksid sellised komplektid olema kättesaadavad erinevatel andmekandjatel (mikrofilmidel või -kaartidel) mitmes hoidlas. (Pillau 1967)

Ka ajaloolane Heldur Palli (1928-2003) tõdes, et informatsiooni leidmine humanitaarteadustes jääb kaugele maha täppisteaduste tasemest ja informatsioonitööd tuleb humanitaarteadustes paremini korraldada. Palli pidas otstarbekaks koostada ühiskonnateaduste märksõnastik (tesaurus) ning vajalikuks varustada artiklid ja raamatud märksõnadega (praegu on see täiesti tavapärane). (Palli 1967) Ta on hiljemgi osutanud vajadusele ja võimalustele arendada teatmetööd, näiteks võtta kasutusele perfokaardid, koostada indekseerimis- ja märksõnastikke. Ühtlasi on ta viidanud, et debatis nõutud ühiskonnateaduste informatsioonikeskust hakati 1960. aastate lõpus tõepoolest Eesti NSV TA Teadusliku Raamatukogu juurde looma. (Palli 1970: 319-321)

Raamatukogunduse ja infotöö pedagoog Enn Vatter ${ }^{9}$ (snd 1937) vastas pika artikliga teaduslik-tehnilise informatsioonitöö teemadel. Ennekõike rõhutas ta teadusliku info üleküllust seoses aina kasvava publikatsioonide hulgaga ning informatsiooni otsimise, kogumise ja ümbertöötamise madalat kasutegurit tööviljakusele. Teaduslik-tehnilise informatsiooni põhiküsimuseks ei pidanud ta mitte automatiseerimist, vaid teadustööde taseme tõstmist ning neis esitatava teabe kontsentreerimist. (Vatter 1968)

Tartu ülikooli raamatukogu direktor Laine Peep ${ }^{10}$ (1932-2001) kritiseeris Kahki mõtteid, osutades, et mikrofilmid on kergelt riknevad ja reklaamitud aparaadid ei ole end arhiivipraktikas tõestanud. Infotöötlemise sõlm-

\footnotetext{
${ }^{8}$ Folklorist, on olnud nii kirjandusmuuseumi rahvamuusika- ja koreograafiasektori kui ka KKI rahvamuusika sektori juhataja.

${ }^{9}$ Vatter oli aastatel 1968-1969 Eesti Teadus- ja Tehnikainformatsiooni ning Majandusuuringute Instituudi (lühendatult: Eesti Informatsiooni Instituut) labori juhataja.

${ }^{10}$ Peep oli selles ametis aastatel 1962-1990.
} 
küsimuseks on märksõnastamine, mis nõuab allikate igakülgset läbitöötamist. Peebu arvates olid arvutid humanitaaraladel kasulikud, kuid esialgu olevat masinate tehniline võimekus madal. Peep seadis kahtluse alla iseseisva ühiskonnateaduste informatsioonikeskuse rajamise, mis viiks olemasolevate asutuste fondide dubleerimiseni. Selle asemel soovitas ta korraldada erinevate raamatukogude, muuseumide ja arhiivide katalooge ja nimistuid. (Peep 1968) $)^{11}$

Õigusteadlaselt Hillar Randalult ${ }^{12}$ (1915-1990) ilmus 1968. aasta septembris mõnes mõttes diskussiooni kokku võttev artikkel, mis osutas vajadusele kasutada informatsiooni analüüsiks masinate abi. Randalu soovis, nagu Palligi, luua tesauruseid, uuritavat materjali iseloomustavaid mõistete süsteeme, mis koondaks „informatsiooni-dinosaurused”: tema soovitus oli mitte pusida käsikartoteekidega, vaid alustada masinatele sobiva informatsioonikeele loomist. Randalu osutas ka Majanduse Instituudis juba perfokaartide abil saavutatud tulemustele. Ühtlasi tegi ta asjahuvilistele üleskutse koguneda informaatikaalasele arutelule. (Randalu 1968)

\section{Debatt rahvaluule osakonna ja kirjandusmuuseumi üle}

Paralleelselt aruteluga Eesti humanitaarteaduste tulevikuteedest käis ajalehes Edasi debatt kirjandusmuuseumi ning rahvaluule osakonna funktsioonide üle. ${ }^{13}$ Siingi võib ärgitavaks alguspunktiks lugeda Juhan Kahki artiklit, kuid lisanduvad veel teisedki aspektid. Esiteks tähistas rahvaluule osakond 40 aasta juubelit, mille puhul ilmus 24. IX 1967. aastal Edasis rida lühiartikleid. Nende hulgas oli „Seitse soovi”, mille kirjutas rahvaluule osakonna nimel Ingrid Rüütel (1967a). Seal avaldati soovi väljaannete kiiremaks publitseerimiseks, kurdeti ruumipuudust ning pikaleveninud remonti, väljendati muuseumi lootusi saada instituudi staatus ja kõrgem palgatase, unistati arhiivi- ja teadustööks (nt rahvamuusika helisalvestiste dešifreerimine, tekstiotsingud) vajalike aparaatide ja arvutite ning andmebaaside olemasolust.

Teiseks pidas Herbert Tampere ${ }^{14}$ (1909-1975) oktoobrirevolutsiooni 50. aastapäevale pühendatud Tartu linna muuseumide teaduslikul konverentsil (6. X 1967) ettekande „Eesti Rahvaluule Arhiivi ja Kirjandusmuuseumi folkloristlikest uurimustest ja väljaannetest”. Seal rõhutas Tampere kogumise, korraldamise, uurimise ja publitseerimise omavahelist tihedat seotust ning probleeme, mis kerkisid üles, kui folkloristid viidi eraldi osakonda Keele ja Kirjanduse Instituudis ning arhiivi endine positsioon teadusasutusena kadus. Sellega kaasnes koosseisu ja palkade vähenemine ning erinevad tööetapid kannatasid. Lisaks vahetusid pidevalt seisukohad tervikuna muuseumi ülesannete osas: kas tuleks tegeleda puhtalt museoloogilise tööga või ka teadustööga. Tampere leidis, et asutuse statuudist sõltumata peaks teooria ja praktika, tehniline ja teadustöö igal juhul omavahel seotud olema, rõhutades kirjandusmuuseumi folkloristide suurt erialast panust nii kodu- kui ka välismaal (Tampere 1971: 192-203; Oras 2008: 70-71). Kaastöötajate mälestuste järgi oli Tamperel unistus, et arhiivile omistataks instituudi staatus (Oras

\footnotetext{
${ }^{11}$ Artiklile kirjutas Juhan Kahk 31. V 1968 vastulause, vt Kahk 1968.

${ }^{12}$ Toona Eesti NSV TA Majanduse Instituudi õiguse sektori vanem teaduslik töötaja.

${ }^{13}$ Kirjandusmuuseumi probleemidest ja töistest taustadest vt ka Kään 1966b; Ertis 1967.

${ }^{14}$ Folklorist ja muusikateadlane, rahvaluule osakonna juhataja 1952-1966.
} 
2008: 71), mis võis ühtviisi põhineda ERA omaaegsel loomisel Eesti Rahva Muuseumi autonoomse osakonnana, sõjaeelsel plaanil asutada ERA eraldi sihtasutusena ning reaalsetel vajadustel.

Rüütli „Seitse soovi” ning ehk ka Tampere ettekanne algatasid Edasis omakorda folkloristide emotsionaalse mõtteavalduste ahela. Tartu Riikliku Ülikooli (TRÜ) professor Eduard Laugaste (1909-1994) ${ }^{15}$ kirjutas artikli muuseumitöö olukorrast, kritiseerides rahvaluule osakonna aeglast töökorraldust ja nurisedes pikalt korraldamata materjalide üle. Samuti olid Laugaste meelest põhjendamatud soovid, mis puudutasid arvutite hankimist ja uurimisinstituudiks muutumist. Viimane jätnuks Laugaste arvates museoloogilise töö üldse kõrvale. Kirjandusmuuseumi funktsioonide osas rõhutas Laugaste, et ERA loomisega tekkis asutusele ülesanne hoida, korraldada ja uurijatele kättesaadavaks teha sinna koondatud kogud, samal ajal neid ka järjepanu uurides ja avaldades, samuti olla praktikabaas ülikoolile. Ülejäänud arvamusavaldus keskendus sellele, kas ja mida siiski koguda (sh kirjandusest kopeeritud rahvaluule) ning kas peaks muutma kogumise meetodeid. Kindlasti aga järgis Laugaste joont, mille kohaselt pidi folkloristlik töö olema asutuste (kirjandusmuuseum, TRÜ ja KKI) vahel rangelt jaotatud ning igasugune teadustöö saanuks toimuda ainult koostöös KKI teadlastega. (Laugaste 1967)

Seisukoht, et arhiivil peaks olema vaid teenindav funktsioon, põhjustas aastakümnete jooksul arhiivitöötajate ja Laugaste vahel rohkelt vastasseisu (vt Oras 2008: 72). Vahetult enne Kreutzwaldi päevade toimumist Edasis 24. detsembril 1967 avaldatud vastulauses Laugastele rõhutas rahvaluule osakonna juhataja Ottilie Kõiva ${ }^{16}$ (snd 1932), et muuseumitöötajad ei ole jäänud imemasinaid ootama: aktiivselt tegeldakse vahepeal seisnud mitmesuguse korraldustööga ning museoloogilise töö ja publikatsioonide kõrvalt ei jätku teaduse tegemiseks kaugeltki ametlikku tööaega. ${ }^{17}$ Teatava kindaheitmisena Laugastele soovitas Kõiva TRÜ rahvaluule eriala üliõpilastel enne välipraktikat tutvuda olemasolevate rahvaluulekogudega. Uute töödena mainis Kõiva mikrofilmikoopiate korraldamist, helilintide dešifreerimist ning regivärsside tüpoloogilise koondkartoteegi koostamist. Kõiva leidis, et suurt osa arhiivitehnilisest tööst ei peaks tegema teaduskraadiga inimesed: olukord laheneks koosseisu suurendamisega ning „multiplikatsiooniaparaatide rakendamisega”. Temagi arvas, et instituudi staatus annaks finantsilist ja moraalset tuge. Artikli lõppmõte oli, et folklorist peab töötama seal, kus on materjalid. (Kõiva 1967)

27. detsembril 1967. aastal kirjandusmuuseumis toimunud Kreutzwaldi päevade teine päev oli pühendatud Eesti Rahvaluule Arhiivi juubelile. Ettekannetega esinesid Herbert Tampere („40 aastat Eesti Rahvaluule Arhiivi asutamisest”), Richard Viidalepp („Kogumistööst Eesti Rahvaluule Arhiivi ajal”) ja Eduard Laugaste („Rahvaluule varakamber, vaadatuna Tartu Riikliku Ülikooli poolt”) (Laido 1967; EKM arhiiv, n 1, s 540, $12^{18}$ ). Kreutzwaldi päevadest ilmus ülevaade Heino Kääni (snd 1935) sulest 1967. aasta lõpul. ${ }^{19}$

${ }^{15}$ Ühtlasi kirjandusmuuseumi teadusliku nõukogu liige.

${ }^{16}$ Folklorist, rahvaluule osakonna juhataja aastatel 1966-1977.

${ }^{17}$ Teadustöö tegemist puhkuse ja une arvelt on maininud mitmed tollased töötajad (Oras 2008: 71).

${ }^{18}$ Artikkel järgib 2017. aasta kevade jooksul korrastatud EKM arhiivinimistu numeratsiooni.

${ }^{19}$ 1966. aasta sügisel avaldas Heino Kään Edasis viieosalise ülevaate muuseumi tegevusest, olles ka omajagu kriitiline (nt Kään 1966a, 1966b). 
Lisaks väga põgusale konverentsi kirjeldusele tõstis ta esile küsimusi muuseumi osakondade tehtud ja tegemata töödest, ning sedagi, et kirjandusmuuseumi kui vabariikliku tähtsusega asutuse probleeme ei peaks otsustama vaid majasiseselt (Kään 1967).

Kirjandusmuuseumi direktor Eduard Ertis ${ }^{20}$ (1915-1994) mainis konverentsi avasõnades, et muuseumil on vaja tegeleda mitmesuguste uurimisteemadega, sest see hoiab võrdsel arengutasemel rahvusteaduste erinevaid alasid, samal ajal põhjustab teemade kirjusust ka teadusharude ja teadlaste spetsialiseeritus. Muuseumi kogumistöö tulemused olevat rikkalikud, kuid korraldustööde mahajäämuse põhjusena tõi Ertis välja jätkuvalt väikese koosseisu. (EKM arhiiv, n 1, s 540, 1 28) Laugaste keskendus ettekande resümee järgi taas asutustevahelisele rollijaotusele, üliõpilaste rakendamisele arhiivi korraldustöös aastakümnete vältel ning arhiivimaterjalide kasutamisele üliõpilaste uurimistöödes, aga ka ühistele (tulevastele) uurimisteemadele ja publitseerimisele (EKM arhiiv, n 1, s 540, 1111-116v). Konverentsi protokolli järgi selgitasid Ottilie Kõiva ja Ingrid Rüütel arutelul, et rahvaluule osakonna põhiressursid on suunatud korraldustööle, kuid jätkata tuleb ka rahvaluule kogumist, sest mõndagi võib asendamatult kaduda (EKM arhiiv, n 1, s 540, 1 18). ${ }^{21}$

1968. aasta jaanuaris jätkusid Edasis arvamusavaldused. August Annist ${ }^{22}$ (1899-1972) möönis, et muuseumi peamine ülesanne on kogude täiendamine, kättesaadavaks tegemine ja publitseerimine. Ta pooldas „elektrofotograafiliste paljundusaparaatide" arhiivi toomist (nagu olid juba olemas Soome Kirjanduse Seltsil), mis lihtsustanuks materjalide korraldustööd ning edendanuks näiteks rahvalaulude trükki jõudmist. Annist osutas, et muuseum peab olema ka uurimisasutus. (Annist 1968)

KKI-st võttis sõna Ülo Tedre ${ }^{23}$ (1928-2015), kes kahetses kunagist teadurite eraldamist materjalidest, mis ei võimalda KKI folkloristidel aidata kaasa korraldamistööle. Olles laias laastus nõus Laugaste väidetega korraldustöö osas, pooldas ta aga keskarhiivi ideed ning nii KKI kui ka ülikooli rahvaluule kateedri kogude toomist Tartusse (mõlemad kogud asuvadki tänaseks ERA-s). Siiski osutas Tedre, et kogude säilitaja ülesandeks on ühtlasi nende korraldamine ja kättesaadavaks tegemine, leides, et rahvaluule osakonna teadustöötajate osalus tehnilises töös on vältimatu ning paljundusaparaadid on küll vajalikud, kuid vaid osaliselt abistavad elemendid. Samuti leidis Tedre, et KKI teadlaste uurimust ettevalmistav tehniline töö arhiivimaterjalidega peaks olema kõige lihtsam ja vähem aeganõudev. Ka leidis ta, et väike arhiivikollektiiv on killustatud paljude ülesannete täitmise vahel. (Tedre 1968) Asutuste lahutamine ja sellest tõukunud probleemid oli üks teema, mida Tedre oma artiklites hiljemgi rõhutas (nt Tedre 2015: 161, 162, 169).

Kirjandusmuuseumi direktor Eduard Ertis kirjutas selle debati lõpetuseks muuseumi töödest ja plaanidest ning haprast tasakaalust nende vahel. Ertis rõhutas, et muuseumis tehakse palju lisatöid, nagu konsultatsioonid, ekskursioonid, retsensioonid, väljasõidud harulduste leidmiseks jne. Ta möönis, et 1950. aastail võeti ehk liiga innukalt ette mõningaid plaane. Ertis käis välja

\footnotetext{
${ }^{20}$ Ametis aastatel 1954-1989.

${ }^{21}$ Muudeks arutlusteemadeks konverentsil olid publitseerimis- ja tehnilise töö raskused, humanitaarteaduste halb olukord, KKI tagasitoomine Tartusse ja mõned teaduslikud küsimused (EKM arhiiv, n 1, s 540, 1 19-22).

${ }^{22}$ Rahvaluule- ja kirjandusteadlane, kirjanik ja tõlkija.

${ }^{23}$ Folklorist, KKI rahvaluule sektori juhataja 1962-1991.
} 
eraldi fondide osakonna loomise mõtte, kuid ei pidanud seda kõikide probleemide lahenduseks. Kirjandusmuuseum olla püüdnud soodustada ülikooli ja instituudi uurijate teenindamist kõikide võimaluste piires ning samas teinud koostööd mõlema asutusega korraldus- ja säilitustöös. (Ertis 1968)

\section{Vestlusring kirjandusmuuseumis}

Oma artiklites tegid osapoolte kokkusaamiseks üleskutse nii Laugaste, Tedre, Kään kui ka Ertis ning see toimus 25. jaanuaril 1968 kirjandusmuuseumis. Kohtumisest avaldati kokkuvõte „Edasi vestlusringis” (Edasi 1968), mille kaudu avalikkus sai aimu kirgliku arutelu teemadest. Lisaks ajalehes avaldatule on Eesti Kirjandusmuuseumi arhiivis alles säilik kohtumise materjalidega, kus on enamiku Edasis avaldatud artiklite väljalõiked, ärakiri direktor Ertise koostatud kohtumise kokkukutsumise põhjendusest (ennekõike sooviga kõrvaldada kirjandusmuuseumi puudusi, osutusega Heino Kääni artiklile) Teaduste Akadeemia presiidiumile ja ühiskonnateaduste osakonnale, TRÜ ajaloo-keeleteaduskonna dekaanile ja ajalehe Edasi toimetajale, ning kohtumise märkmed (EKM arhiiv, n 1, s 553). Kohtumisest võtsid osa ajakirjanduses sõna võtnud pooled, TRÜ, KKI, Zooloogia-Botaanika Instituudi, Ajaloo Instituudi ja kirjandusmuuseumi teadurid, lisaks teiste Tartu muuseumide ja ajalehe Edasi esindajad, samuti Teaduste Akadeemia ühiskonnateaduste osakonna akadeemik-sekretär Joosep Saat ning kirjastuse Eesti Raamat peatoimetaja Aksel Tamm (snd 1931) (EKM arhiiv, n 1, s 553, 17 ).

Edasis ilmunud kokkuvõttes nenditi, et kogumistöö tagaplaanile jätmine materjalide süstematiseerimiseks ja kättesaadavaks tegemiseks ei ole hea, kuna vanem rahvaluule ja trükisõna vajab kiiresti talletamist ning pole olemas teemat, mida saaks korrastamise huvides kõrvale jätta. Fondid ning osakondadele esitatud ülesanded ja nõuded on kasvanud, koosseis aga jäänud minimaalseks: kirjandusmuuseumis oli 1968. aasta alguse seisuga 33 töötajat, ${ }^{24}$ vaja olnuks hinnanguliselt 70-80. Võrdluseks toodi Eesti Rahva Muuseumi kunagised osakonnad, nüüdsed eraldiseisvad muuseumid, mille koosseis oli kõvasti kasvanud (etnograafiamuuseumis üheksalt inimeselt 44-le, Tartu kunstimuuseumis kolmelt 26-le). Kõne all oli palkade väiksus võrreldes teiste asutustega, ${ }^{25}$ võimalus, et muuseum tõepoolest võiks saada instituudi staatuse, publikatsioonide ilmumise kiirendamine, koostöö parandamine ülikooliga, muuseumi üldine suhtlus avalikkusega ning administratiivsed küsimu-

${ }^{24}$ Osa kaadrist on jäetud üles lugemata, vt järgmist allmärkust.

${ }^{25}$ KKI-s töötas 1967. aasta 1. jaanuari seisuga 109 töötajat, kirjandusmuuseumis 46 (Ahven 2007: 416; EKM arhiiv, n 1, s 547). KKI-s oli 1967. aastal kraadita nooremate teaduslike töötajate palk kuni 98 rubla. NSV Liidu Ministrite Nõukogu Riikliku Töö ja Töötasu Komitee määrusega 20. IX 1967 tõsteti miinimumpalk teadusasutustes 60 rublale. Nii tõsteti alates 15 . XII 1967 palka 27 inimesel, v.a nooremad teaduslikud töötajad, bibliograafid ja insenerid. Vanemlaborantide palk oli 1968. aastaks seega 70 rubla (enne 55), bibliograafide kuupalgad 50-74 rubla. 1970. aastal KKI koosseisu üle toodud kirjandusmuuseumi rahvaluule osakonna vanem teaduslik töötaja Erna Normann sai uue töötasuna 210 rubla kuus, mida oli senisest kaks korda rohkem. 1971. aastal on vanema teadusliku töötaja palk 250 rubla (Ahven 2007: 421-422, 485, 515). Kirjandusmuuseumis oli aastail 1967-1968 vanema teadusliku töötaja kraaditasuta kuupalk 100-105 rubla, vanembibliograafil 105 rubla, bibliograafil 83 rubla (EKM arhiiv, n 1, s 547, 1 51; EKM arhiiv, n 1, s 574, 1 34-35). 
sed. Vahetult enne vestlusringi oli Teaduste Akadeemia presiidium võtnud vastu otsuse koostada kõigile allasutustele üksikasjalik viisaastakuplaan ja perspektiivplaan kuni aastani 1985. (Edasi 1968) Sellest lähtuvalt asuti arutelu järel ka vastavaid plaane koostama.

Kui Edasi juurest pöörduda kirjandusmuuseumis leiduvate arhiivimaterjalide poole, ${ }^{26}$ avaneb oluliselt kirjum pilt, mida siinkohal saab avada vaid põgusalt. Esiteks laekus Edasi toimetusele kaks avaldamisele mitte kuulunud teksti: käsikirjade osakonna juhatajalt Helene Siimiskerilt (1924-2012) ja kirjandusteadlaselt Sergei Issakovilt (1931-2013). Siimisker viitas peavarahoidjate ja teaduslike sekretäride tihedale vahetumisele ja sellest tulenevatele juhtimisprobleemidele; muuseumi ennastohverdav kollektiiv olla muutunud ükskõiksemaks ning lahenduseks oleks osakondade juurde probleemnõukogu moodustamine. Issakov tegi oma kirjas ettepanekuid muuseumitöö praktiliseks korraldamiseks. (EKM arhiiv, n 1, s 553, l 10, 19-21)

Koosolekul tõdeti korduvalt, et kuidagi ei jõuta lahendusteni, kurdetakse vaid muresid, selgete vastusteta jäävad küsimused milliseid plaane luua? ja kuidas edasi? Arutelus, kas rõhuda korraldustööle, kogumisele või teaduslikele väljunditele, pakkus Paul Ariste ${ }^{27}$ (1905-1990) välja lahenduse seada uus eesmärk: uus materjal korda, sest just selle kättesaamisega olevat rohkem probleeme. Ariste nentis samal ajal, et tema on kõik vajaliku oma tööks kätte saanud (EKM arhiiv, n 1, s 553, 1 12). Ingrid Rüütel kordas taas, et iga valmiv väljaanne peab endast järele jätma korras kartoteegi, ning kohatud on väited, et tahetakse teha puhast teadust (EKM arhiiv, n 1, s 553, l 12). Etnograafiamuuseumi direktor Aleksei Peterson ${ }^{28}$ (1931-2017) tõdes oma sõnavõtus, et etnograafia ja rahvaluule üksteisest kaugenemine pole normaalne. Samuti oli ta kategooriliselt vastu kogumistöö vähendamisele, põhjendades seda materjali kaotsiminekuga. (EKM arhiiv, n 1, s 553, 1 13, 26)

Ottilie Kõiva väljendas koosolekul uuesti muret kunagise asutuste ja töötajate lahkulöömise üle, avaldades lootust, et probleemne olukord lahendub muuseumi ja KKI ühinemisega, ${ }^{29}$ nii et igal folklooriliigil oleks oma korraldaja ja uurija. Ta leidis, et kui KKI oleks jäänud Tallinnasse viimata, oleks arhiivitöö jaoks kokku hoitud palju aega ja raha ning ära jäänud avalik vaidlus korraldustöö üle. (EKM arhiiv, n 1, s 553, l 21) Kõiva kommentaar näitab, kui palju tegid 1940. aastate ümberkorraldused inimestele haiget ja kui pikkadeks aastakümneteks see neid mõjutama jäi.

August Palm ${ }^{30}$ (1902-1972) bibliograafiaosakonnast loetles võrdlevalt osakondade vajadused uue tööjõu järele, pani ette koostada vastav plaan koos tööjõu vajaduse loeteluga ning esitas terava küsimuse, kas kirjandusmuuseumil on olnud üldse kasu Teaduste Akadeemia süsteemi kuulumisest: Moskvale ei ole muuseum tähtis ning raha suunatakse loodusteadustele ja tehnikaaladele, jättes rahvuslikud teadused tagaplaanile (EKM arhiiv, n 1, s 553, 1 28-30).

Teaduste Akadeemiat esindav Joosep Saat (1900-1977) on vastuseks kommenteerinud, et muuseumi töötajaid ei ole süüdistatud laiskuses ning huma-

\footnotetext{
${ }^{26}$ Arutelust on säilikus neli erinevat konspekti, millest siin on kasutatud kahte põhjalikumat.

${ }^{27}$ Keele- ja rahvaluuleteadlane, eesti fennougristika koolkonna rajaja, TRÜ soome-ugri keelte kateedri juhataja ja professor, akadeemik.

${ }^{28}$ Etnoloog, direktorina ametis aastatel 1958-1992.

${ }^{29}$ Uue hoone asukoht pidi olema Tartu. Lähemalt Ahven 2007: 475-476.

${ }^{30}$ Kirjandusteadlane ja bibliograaf.
} 
nitaarteadustele on õigusega tähelepanu juhitud. Ta kaitses vaidlustes Teaduste Akadeemiat, öeldes, et arenguteks on vaja ühistööd ning TA-l pole võimalik kõiki ühiskonnateadusi arendada. Saat osutas, et kirjandusmuuseumi teemad ei ole kõrgemates komiteedes taotlustel läbi läinud ning kuigi hetkel tööjõudu juurde ei saa, ei maksa lootust kaotada. (EKM arhiiv, n 1, s 553, 1 9v, 31) Võib arvata, et kohalolijaid selline vastus ei rahuldanud.

Folklorist Hilja Kokamägi (1923-2017) jõulistele etteheidetele Teaduste Akadeemia presiidiumi aadressil (EKM arhiiv, n 1, s 553, 1 14) vastas Heino Kään, et kui presiidium ei suuda küsimusi lahendada, tuleb pöörduda valitsuse poole. Kään tõdes ka, et planeerimine käib sageli tutvuste kaudu, väga vajalik on läbimõeldud plaan, ning kahetses, et arutelus jäi tagaplaanile tõsiasi, et kirjandusmuuseum on kultuuriasutus, mis peab kogusid populariseerima. (EKM arhiiv, n 1, s 553, 1 14, 41, 42) Kunstimuuseumi direktor Vaike Tiik (1921-2016) leidis, et kirjandusmuuseumi probleemilahenduseks koostatav perspektiivplaan on vajalik, kuid kuna elu muudab plaane, oli tema nende osas skeptiline. Pearõhk võiks olla museoloogilisel tööl, kuid kvalitatiivne korraldustöö kaasneb siiski uurimustega. (EKM arhiiv, n 1, s 553, 1 35-36)

Ajaloolane Ea Jansen (1921-2005) märkis, et ühiskonnateaduste arengu perspektiivide suhtes tuleb arvestada informatsiooniteenistuse viletsust. Esimeseks sammuks oleks ühiskonnateaduste asutuste esindajate vastav nõupidamine, kaugemas perspektiivis peaks silmas pidama masinate rakendamist ning uute meetodite tundmaõppimist. Jansen osutas, et inimkonna silmaks olevate humanitaarteaduste areng on aktuaalne kogu maailmas: kujunevad välja uued teadusharud ning otsitakse uusi meetodeid. Ühtlasi osutas Jansen, et teaduse populaarsemaks tegemiseks tuleb sellest ka huvitavalt kirjutada. (EKM arhiiv, n 1, s 553, 18v, 39)

Avalikus debatis üheks tugevaks kriitikuks olnud Eduard Laugaste püüdis arutelul end mitmel juhul kaitsta, paludes end pigem võtta muuseumitöötajate nõuandjana. Samas oli ta TRÜ kogude muuseumisse toomise vastu, kuna üliõpilaste kogud kuuluvat ülikoolile. (EKM arhiiv, n 1, s 553, 1 9, 11)

Eestimaa Kommunistliku Partei Tartu linnakomitee ülesandel kohal viibinud Alice Habermann ${ }^{31}$ (1905-1993) osutas, et humanitaaria saab end maksma panna vaid iseenda autoriteedi varal ning kõnesolevates küsimustes ollakse ise kõige kompetentsemad. Arutelu rõhuasetus olevat vale: igaüks on tahtnud saada vastust ainult ennast huvitavale küsimusele. Teaduslik efekt peaks aga olema maksimaalne ning tuleb planeerida, mida saab ära teha olemasolevate jõududega. Habermann pani omakorda ette moodustada kolleegium ning taktika ja strateegia küsimused läbi töötada: kui suudetakse näidata töö eesmärke ning tegelikke tulemusi, siis saadakse ka vajalikud vahendid. (EKM arhiiv, n 1, s 553, 1 15, 43, 44)

Kokkuvõttes märkis Eduard Ertis, et ehkki vestlust oli raske organiseerida, on ta rahul koosoleku toimumise ja probleemidest rääkimisega. Ta pakkus samuti, et mitmete küsimustega võiks pöörduda kõrgematesse asutustesse ning majanduslikke probleeme lahendada ühiselt, lubades ühtlasi, et muuseumi teaduslik nõukogu hakkab teadusliku ja museoloogilise töö põhiprobleeme arutama järgmisest koosolekust alates. (EKM arhiiv, n 1, s 553, 1 15, 45-46) On huvitav, et veidi varasemal osakonnajuhatajate koosolekul 15. jaanuaril 1968 osutas Ertis, et teadustööde planeerimisega tuleb olla

${ }^{31}$ Kirjandusmuuseumi direktor aastatel 1945-1951. 
ettevaatlik (ilmselt tööde mahtu ja venimist silmas pidades), ning tõdes, et aktuaalne remondi- ja majanduslik olukord ei lahene niipea (EKM arhiiv, $\mathrm{n} 1$, s $552,11,2)$.

Juhan Kahk kirjeldas debati algul toonast hetkeseisu üsna luuleliselt pimedas varandusekambris seismisena (Kahk 1967: 3), viidates kultuurivaradele, mis on jäänud uurijatele kättesaamatuks ja „surnuks”. Küsimus oli aga tehnilise olukorra piiratuses, vahel ehk ka selgema visiooni puudumises võimalikest efektiivsetest lahendustest. Folkloristide mõttevahetuse põhjuseks oli nende killustatus, mõningane personaalne vastasseis ja asutuste tööjaotus, arhiivimaterjalide suur hulk ja hoogne juurdekasv ning inimeste vähesus. Et kõnealused teemad puudutasid osalejaid üsna isiklikult, ei jätkunud laiemaks vaateks alati rahumeelsust. Samal ajal oli ühiseks eesmärgiks siiski olukordadele lahenduste leidmine, kuigi selgekujulist plaani ei tekkinud. Tehniliste abivahendite kasutamise ning üldise humanitaarteaduste arengu küsimused, sh eriti selles osas, mis puudutas humanitaarteaduste ühendamist infotehnoloogiaga, käisid läbi pea kõigi debattides osalenute arvamustest. Oli selge, et humanitaarteadustes oli tekkinud tugev soov ja vajadus suurema sidususe järele infotehnoloogiaga ning tegevusi püüti ka vastavalt suunata.

1968. aasta veebruari lõpus toimunud kirjandusmuuseumi teadusliku nõukogu koosolekul jätkusid kired tegemata ja tehtud tööde ümber. Kohalolijad arutlesid kirjandusmuuseumi perspektiivplaani ehk n-ö tööde soovnimekirja üle 1970. aastateks (vt EKM arhiiv, n 1, s 568). Nõukogu soovitas järjekindlalt nõuda Teaduste Akadeemialt tehnikat ja tööjõudu. Muuseumi töötajad osutasid, et vajaliku korraldustöö ja publikatsioonide hulk võrreldes töötajate pea olematu juurdekasvuga on tekitanud raskusi, kuid kõigega püütakse hakkama saada. Teaduslik nõukogu võttis perspektiivplaani siiski vastu. Arutati ka juurdeehituse ja töötajaskonna kasvu taotlusi TA-le. Muuhulgas soovisid rahvaluule osakonna töötajad teha suuremat koostööd KKI rahvaluule sektoriga nii korraldustöö kui ka ekspeditsioonide osas, millele protokollis selget vastust ei leidu; küll väljendas Ülo Tedre koosoleku teises pooles, et ootab muinasjuttudega tegelemisel rahvaluule osakonnalt abi KKI-le. (EKM arhiiv, n 1, s 555, 1 1-10) Arutelu tehnilise töö ning teaduslike probleemide üle jätkati pikalt ka mais toimunud teadusliku nõukogu koosolekul (EKM arhiiv, n 1, s 555, 1 11-18). Samuti maikuus toimunud muuseumi osakonnajuhatajate koosolekul arutleti TA presiidiumi otsuse üle, kus nõuti muuhulgas arhiivimaterjalide järjekindlat korrastamist (EKM arhiiv, n 1, s 552, 1 18, 19).

Septembrikuise teadusliku nõukogu koosoleku protokolli kohaselt on TA muuseumile vastanud, et arvestab asutuse soovidega, kuid ei luba taotletud määral juurdeehitust ning töötajate arvu kasvu (EKM arhiiv, n 1, s 555, 1 22). Ühtlasi nähtub protokollist, et jaanuaris tuliste sõnavõttude saatel räägitut ja otsustatut on püütud teostada: parandada korrastatud materjali seisu, rakendada tööle väiksemaid kolleegiume, anda avalikkusele ülevaade kogumisüleskutsetele vastuseks saadetust jm (EKM arhiiv, n 1, s 555, 1 27-28).

Tehnika hankimine ja tööjõu suurendamine oli kirjandusmuuseumis läbiv tegevus ka järgmistel kümnenditel ning seis paranes järjepidevalt, sh materjalide korrastatus ja kättesaadavus. Küll jäi nõukogude ajal saamata instituudi staatus (samuti ei ühinenud kirjandusmuuseum KKI-ga) ja sellest tulenevad kõrgemad palgamäärad. 


\section{Arutelu seosed tänapäevaga}

Tänapäeval oleme silmitsi mõnevõrra teistsuguse olukorraga kui viiekümne aasta eest. Paljud küsimused on lahendatud, kogusid korrastatud ja hulgaliselt juurde kogutud, nii trükitud kujul kui ka digitaalselt kättesaadavaks tehtud. Kogumis-, korraldus- ja uurimistöö on muutunud tehnilisemaks, uurimisaines digitaalsemaks. Toonastest aruteludest torkab silma mitme osaleja ettenägelikkus: tänagi on selge, et ühiskonna jaoks jätkusuutlike, atraktiivsete lahenduste loomiseks peavad humanitaaria ja infotehnoloogia tegutsema lähestikku. Samal ajal arutleme jätkuvalt selle üle, kuidas humanitaariat ja infotehnoloogiat paremini ühendada ning vastastikku valdkondlikke teadmisi vahendada. Digihumanitaaria võiks olla enesestmõistetav osa humanitaariast, mitte segadusttekitav täiend (Lindström, Uiboaed 2017).

Arvutite kasutamine folklooriandmete töötlemisel sai hoogu 1980. aastatel. Kuna 1967. aastast osutatud soovid puudutasid mitmel puhul etnomusikoloogiat, tuleb mainida, et kirjandusmuuseumi endises etnomusikoloogia osakonnas loodi pikaaegse töö tulemusena regiviiside andmebaas ning selle alusel arvutimeetod regiviiside tüpoloogia koostamiseks ja rahvamuusika võrdlevaks uurimiseks (Rüütel 2009: 208-209). Praeguseks on folkloristikas kasutusel kümneid eri aegadel projektipõhiselt loodud andmebaase. Käesoleval hetkel on probleemiks nende liidestamine.

Tehnilised võimalused on toonud teisi muresid: andmete ligipääsu juures peab ühelt poolt arvestama kaastööliste endi soovide, aga ka hirmudega, ning teisalt rangete nõuetega eetika, isiku- ja andmekaitse osas. Teaduses kehtib samal ajal üha rohkem avatud teaduse ja andmete vaba juurdepääsu nõue. Paradoksaalselt ei lase avatud teadus täiel määral kaitsta kaitsmist vajavat. Lisaks ei ole folklooriarhiivid „surnud”, vaid elavad teadmuskeskused, mis ühendavad eri sajanditest ja eri keeltest-kultuuridest pärit materjale, esindavad teaduslikke, õppe-eesmärgilisi, koduloolisi ja perepärimuslikke huve ning teevad koostööd nii teiste institutsioonide, kogukondade kui ka üksikisikutega. Avatuse-suletuse vahel balansseerimine on keeruline, ent loodetavasti mitte võimatu. Arhiivitöö tulevikku silmas pidades on oluline lahendada küsimus, millises formaadis ja vormis tuleks tänapäevast materjali säilitada ja arhiveerida, et see oleks uurijatele kasutuskõlblik mitmete aastakümnete pärast. See nõuab häid ennustajavõimeid tehnoloogiliste arengute osas. Ilmselgelt on siingi koostöövajadus infotehnoloogia ja humanitaaria vahel.

Väga paljud teadlased tegelevad keerulistele olukordadele lahenduste leidmise või leiutamisega. On ka mõistetav, et teadustööle lisanduvad uued ülesanded või projektid, plaane peab erinevatel põhjustel muutma. Tehnika, rahastuse ja tööjõu teemasid võiks korrutama jäädagi. Tipptulemusteni püüeldakse paraku teadlaste endi tervise ja pere arvelt, stabiilse tugistruktuuri puudumine ei lase ka püsivalt teha heal tasemel teadust.

Projektipõhisust siiski veel üsna suures ulatuses ette kirjutav teaduspoliitika suunab teadlasi tegelema rohkem administratiivsete ülesannetega: korraldustöö, taotluste ja aruannete koostamise, projektijuhtimise, lisaks ka juhendamise, loengupidamise ja muuga (nt Lukner 2016: 46). Nende ülesannete täitmine on muidugi eelduseks, et oleks üleüldse võimalik seatud eesmärke saavutada. Ka eduka uurimisprojekti puhul tuleb uurimisrühmadel loota jätkurahastusele, vältimaks teema järsku lõppemist. He a jät k u s u u t - 
lik teadus vajab rohkem aega ja püsivamaid ressursse, kui võimaldab mõne aasta pikkune projekt - sellel teemal on avalikult palju sõna võetud (nt Niinemets 2015; Ukrainski jt 2015; Koppel jt 2016; Maidla 2017). Uued eesmärgid rahastuses ${ }^{32}$ ja karjäärimudelis (näiteks tenuuri rakendamine Tallinna Tehnikaülikoolis) ei paku esialgu lõplikke lahendusi. Tänase teaduspoliitika, rahastuspõhimõtete ja karjäärimudeli kaugemate tagajärgede osas tuleb loota, et muudatusi tehakse läbimõeldult ning neil arengutel on positiivseid külgi. Humanitaarteadused, olles jätkuvalt vägagi arenemisvõimelised, on tõepoolest inimkonna silm: meil on ka tänapäeval vajadus ühiskonnale silma vaadata, mõista ja seletada selles peegelduvat.

Artikli valmimist on toetanud Euroopa Liit Euroopa Regionaalarengu Fondi kaudu (Eesti-uuringute Tippkeskus) ning Haridus- ja Teadusministeerium (uurimisprojekt IUT22-4 „Folkloor kultuurilise kommunikatsiooni protsessis: ideoloogiad ja kogukonnad”).

\section{Käsikirjalised allikad}

EKM arhiiv = Eesti Kirjandusmuuseumi arhiiv:

EKM arhiiv, n 1, s 540 - Kreutzwaldi-päeva teadusliku konverentsi materjalid.

EKM arhiiv, n 1, s 547 - 1967. a. eelarve, kinnitatud töötasufond ja kapitaalmahutuste plaanid.

EKM arhiiv, n 1, s 552 - Osakonnajuhatajate koosoleku protokollid.

EKM arhiiv, n 1, s 553 - „Edasi” vestlusringi materjalid.

EKM arhiiv, n 1, s 555 - Teadusliku Nõukogu koosolekute protokollid.

EKM arhiiv, n 1, s 568 - Osakondade (v.a Arhiivraamatukogu) museoloogilise töö perspektiivplaan alates 1968. a., eesti retrospektiivse rahvusbibliograafia 20-aasta plaan (1963.-1982. a.) ja seletuskiri selle juurde.

EKM arhiiv, n 1, s 574 - 1968. a. eelarve, kinnitatud töötasufond ja kapitaalmahutuste plaanid.

\section{Kirjandus}

Ad a m s o n, Virve 1990. Bibliograafia osakonna töösuunad ja kartoteegid. - Juurtega sajandite mullas. Kogumik Fr. R. Kreutzwaldi nim. Kirjandusmuuseumi 50. aastapäevaks. Toim Meelis Kahu. Tallinn: Eesti Raamat, lk 92-98.

A hve n, Eeva 2007. Pilk paberpeeglisse. Keele ja Kirjanduse Instituudi kroonika 1947-1993. Toim Maria-Maren Sepper. Tallinn: Eesti Keele Sihtasutus.

Annist, August 1968. Meie rahvaluule hiigla-aarded ootavad tõepoolest „imemasinaid". - Edasi 14. I, nr 12, lk 3.

Annus, Endel 1966. Teadlaste ja spetsialistide teenistuses. - Sirp ja Vasar 28. X, nr 44, lk 2 .

Edasi 1968 = Kirjandusmuuseumi probleemid ja perspektiivid. - Edasi 17. II, nr $41, \mathrm{lk} 2$.

${ }^{32}$ Vt lähemalt „Uurimistoetuste ja tegevustoetuse uus kontseptsioon” (2016) http://www. etag.ee/wp-content/uploads/2016/10/Uurimistoetuste_ja_tegevustoetuse_uus_süsteem_ ETAg_2016.pdf 
Ertis, Eduard 1967. Probleem kerkib probleemi kõrvale. - Edasi 21. III, nr 67, lk 2.

Ertis, Eduard 1968. Kirjandusmuuseumis: plaanid - aruanded - töö - ettepanekud. - Edasi 24. I, nr 20, lk 2.

Gor š ič, Ave 2015. Seitse soovi. Ootused ja täitumised 1967-2015. - Mäetagused, nr 62, lk 95-100.

Ka h k, Juhan 1967. Eilses, tänases ja homses. - Sirp ja Vasar 15. IX, nr 37, lk 3-5.

Kahk, Juhan 1968. Vastuseks Laine Peebule. - Sirp ja Vasar 31. V, nr 22, lk 7.

Keel ja Kirjandus 1967 = Bibliograafide saavutusi ja päevamuresid. - Keel ja Kirjandus, nr 1, lk 58-59.

Koppel, Andres, Jaans on, Karin, Rutiku, Siret 2016. Teaduse rahastamise süsteem vajab ümberkorraldamist. - Eesti Teadus 2016. SA Eesti Teadusagentuur, lk 45-46. http://www.etag.ee/wp-content/uploads/2014/01/TA_teaduskogumik_veeb-1.pdf (28. VIII 2017).

Krikm a n n, Arvo 2000. Eesti lühivormide allikaloost [võrguteavik], ptk 8. http:// www.folklore.ee/ kriku/ALLIK/ (22. IX 2017).

Ku uli, Olaf 2002. Sula ja hallad Eesti NSV-s: kultuuripoliitikast aastail 19531969. Tallinn: O. Kuuli.

Kõiva, Ottilie 1967. Muuseumitöötajad pole jäänud, käed rüpes, imemasinaid ootama. - Edasi 24. XII, nr 299, lk 3.

Kään, Heino 1966a. Kirjandusmuuseumis 4. Ajakirjanduse koondnimistud. Edasi 16. XI, nr 269, lk 2.

Kää n, Heino 1966b. Kirjandusmuuseumis 5. Iga päev pole pühapäev. - Edasi 17. XI, nr 270, lk 2.

Kää n, Heino 1967. Kreutzwaldi päevast ja Kreutzwaldi muuseumist. - Edasi 31. XII, nr 305, lk 3.

Laid o, Evi 1967. Kreutzwaldi päev. - Edasi 24. XII, nr 299, lk 3.

Laugaste, Eduard 1967. Mõningaid mõtteid museoloogilisest tööst eesti folkloristikas. - Edasi 17. XI, nr 293, lk 2-3.

Lindström, Liina, Uiboaed, Kristel 2017. Valdkondade vastasseis? Digihumanitaaria - see ongi tänane humanitaaria. - Novaator. http://novaator.err. ee/600621/valdkondade-vastasseis-digihumanitaaria-see-ongi-tanane-humanitaaria (28. VIII 2017).

Lukner, Heli 2016. Järelkasv ja teadlaskarjäär. - Eesti Teadus 2016. SA Eesti Teadusagentuur, lk 46-47. http://www.etag.ee/wp-content/uploads/2014/01/TA teaduskogumik_veeb-1.pdf (28. VIII 2017).

Maidla, Margus 2017. Millist teadust vajab Eesti? Ehk Teadussüsteemi mitmekesisusest ja järjepidevusest. - Sirp 18. VIII. http://www.sirp.ee/s1-artiklid/ c21-teadus/millist-teadust-vajab-eesti-ehk-teadussusteemi-mitmekesisusest-jajarjepidevusest/ (25. VIII 2017).

Margus, Malev 1966. Metsandus, haljastamine ja retrospektiivne bibliograafia. - Edasi 29. X, nr 255, lk 1.

Niinemets, Ülo 2015. Eesti teadus Euroopa teadusruumis. - Sirp 11. XII. http://www.sirp.ee/s1-artiklid/c21-teadus/eesti-teadus-euroopa-teadusruumis/ (28. VIII 2017).

Or a s, Janika 2008. Viie 20. sajandi naise regilaulumaailm. Arhiivitekstid, kogemused ja mälestused. (Eesti Rahvaluule Arhiivi Toimetused 27.) Tartu: Eesti Kirjandusmuuseumi Teaduskirjastus.

Palli, Heldur 1967. Millest siis alata? - Sirp ja Vasar 1. XII, nr 48, lk 4. 
Palli, Heldur 1970. Ajaloobibliograafia ja teaduslik informatsioon. - Leninlik etapp eesti ajalooteaduses. Toim Endel Laul. Tallinn: Eesti Raamat, lk 310-321.

Peep, Laine 1968. Alustada tuleb kohe - aga asjalikult! - Sirp ja Vasar 24. V, nr 21, lk 3, 7.

Pillau, Endel 1967. Vanema perioodika bibliografeerimisest. - Sirp ja Vasar 12. XI, nr 45, lk 7.

Rahva Hääl 1967 = Abinõudest ühiskonnateaduste edasiarendamiseks ja nende osa suurendamiseks kommunistlikus ülesehitustöös. - Rahva Hääl 23. VIII, nr 197, lk 1-2.

Rand al u, Hillar 1968. Tesaurus võidab dinosauruse. - Sirp ja Vasar 6. IX, nr 36, lk 4.

Rü üt el, Ingrid 1967a. Seitse soovi. - Edasi 24. IX, nr 226, lk 3.

Rü ütel, Ingrid 1967b. Tänasest, homsele mõeldes. - Sirp ja Vasar 13. X, nr 41, $1 \mathrm{k} 5$.

Rü ü tel, Ingrid 2009. 30 aastat rahvamuusika sektori sünnist. - Paar sammukest XXV. Eesti Kirjandusmuuseumi aastaraamat 2008. Tartu: Eesti Kirjandusmuuseumi Teaduskirjastus, lk 194-236.

Tam pere, Herbert 1971 [1967]. Kaks ettekannet Eesti folkloristika ajaloost. Paar sammukest eesti kirjanduse uurimise teed. (Uurimusi ja materjale VII.) Tartu: Eesti NSV Teaduste Akadeemia Fr. R. Kreutzwaldi nimeline Kirjandusmuuseum, lk 183-203.

Te d re, Ülo 1968. Vaja on nii inimesi kui ka masinaid. - Edasi 21. I, nr 18, lk 2.

Ted r e, Ülo 2015 [1997]. Tagasivaateid KKI rahvaluulesektori tööle 1947-1990. Mäetagused, nr 61, lk 161-170.

Ukrainski, Kadri, Kanep, Hanna, Timpmann, Kadi 2015. Konkurents teadusrahale. - Sirp 25. IX. http://www.sirp.ee/s1-artiklid/c21-teadus/konkurentsteadusrahale/ (28. VIII 2017).

V att e r, Enn 1968. Kas oleme loonud uue dinosauruse. - Sirp ja Vasar 19. I, nr 3, lk 4.

Ve e r s a lu, Ilse 1966. Ühe suure varaaida võtmed. - Edasi 3. VIII, nr 180, lk 2.

\section{The public debate of 1967-1968 around the Estonian Literary Museum and the humanities}

Keywords: folkloristics, history of science, 1960s, humanities, information technology, Estonian Literary Museum, Estonian Folklore Archives

The article recollects a debate between humanities scholars published in two Estonian newspapers - Sirp ja Vasar and Edasi - in 1967 and 1968. One of the main issues was the prospective implementation of computers and information technology in the preservation of humnities collections as well as in data processing and retrieval in the Estonian SSR. The other hub of the discussion was the Fr. R. Kreutzwald National Literay Museum at the ESSR Academy of Sciences and its folklore department (Estonian Folklore Archives), also touching upon the problems and functions of the collections and personnel of other departments of the museum

The prevailing results of the debate were that humanities should necessarily be encouraged to cooperate with information technology, possibly with the help of a prospective centre of information sciences, while manual handling of data and col- 
lections should be reorganised providing for a conversion to computer-based technologies. As for the Literary Museum, the debate explicated the needs of both the museum staff and the users of its collections, as well as the activities necessary to facilitate the arrangement and accessibility of the collections, including cooperation with other humanities institutions.

Notably, the public debate of 50 years ago reveals some interesting parallels between the then problems of uniting the forces of the humanities and information technology and the present-day field of digital humanities, considering the demand for it as well as its developmental requirements.

Ave Goršič (b. 1979), PhD, Estonian Literary Museum, Estonian Folklore Archives, Researcher,avegorsic@folklore.ee 